\title{
Low Cost Rainwater Harvesting: An Alternate Solution to Salinity Affected Coastal Region of Bangladesh
}

\author{
Kamal Ziaul Islam ${ }^{1, *}$, Md Sirajul Islam², Jean O. Lacoursière ${ }^{3}$, Lisa Dessborn ${ }^{4}$ \\ ${ }^{1}$ Assistant General Manager, Jessore Palli Bidyut Samity-2, Jessore, Bangladesh \\ ${ }^{2}$ Department of Civil and Environmental Engineering (CEED) North South University, Dhaka, Bangladesh \\ ${ }^{3}$ Professor, Kristianstad University, Kristianstad, Sweden \\ ${ }^{4}$ Senior Lecturer, Kristianstad University, Kristianstad, Sweden \\ *Corresponding author: kamalziaulislam@yahoo.com
}

Received September 20, 2014; Revised October 05, 2014; Accepted December 15, 2014

\begin{abstract}
This study investigated the prospect of rainwater harvesting as a low cost alternative potable water supply option along the coastal region of Bangladesh, which is considered as one of the most vulnerable countries in the world due to climate change and resulting sea level rise. Because of increasing salinity intrusion, potable water scarcity become severe at the south-western coastal region of the country. The study area for this investigation was Patkelghata in Satkhira district of Bangladesh located in the same zone. The Satkhira district averages nearly 1,710 $\mathrm{mm}$ rainfall per year. Based on rural housing pattern of the region, a rainwater harvesting system is proposed, which consists of roof catchment, gutters, down pipes, first flush devices, filter chamber and storage tank. The minimum catchment area was assumed to be $6 \mathrm{~m}^{2}$ and storage tank of 2000 liter capacity. Data was collected on the present state of freshwater supply, sources and quality, average rainfall in the region, dry spell period, family size, water use nature, rain water quality and material to be used for storage, etc. Rainwater quality was also tested and the parameters were found to be within Bangladesh's standard limit. After a detail calculation, an approximate cost was assumed to be $\$ 171$ for building and operation of the whole system. A questionnaire survey was also conducted on views and opinion of local people to understand the problems, prospects and the popularity of rainwater harvesting in Bangladesh.
\end{abstract}

Keywords: climate change impact, salinity intrusion, fresh water crisis, rainwater harvesting, design of storage tank, cost analysis, management options

Cite This Article: Kamal Ziaul Islam, Md Sirajul Islam, Jean O. Lacoursière, and Lisa Dessborn, "Low Cost Rainwater Harvesting: An Alternate Solution to Salinity Affected Coastal Region of Bangladesh.” American Journal of Water Resources, vol. 2, no. 6 (2014): 141-148. doi: 10.12691/ajwr-2-6-2.

\section{Introduction}

Bangladesh is a tropical country located between $20^{\circ} 34^{\prime}$ and $26^{\circ} 38^{\prime} \mathrm{N}$ latitude and $88^{\circ} 01^{\prime}$ to $92^{\circ} 41^{\prime} \mathrm{E}$ longitudes. Being located in the Asian monsoon belt, the country experiences a heavy rainfall during monsoon, generally between 1,500 and $3,500 \mathrm{~mm}$. The Satkhira district averages nearly $1,710 \mathrm{~mm}$ rainfall per year [1]. Monsoon usually covers from May to October and occasional rainfall from November to March. During the six month of monsoon period, abundance of rainwater can reduce the dependency on groundwater to a great extent. It is revealed from the literature that about $15 \%$ of the total supply can be met by harvested rainwater [2]. Satkhira district has around $3858 \mathrm{~km}^{2}$ of land with a roof area of $0.56 \mathrm{~km}^{2}$ as there are around 5,000 concrete houses [3]. Institute of Water Modeling (IWM) recently estimated that around 149,160 million liters of water can be harvested during monsoon in the region with the current rate of rainfall. Urban and rural water supply in Bangladesh is mainly based on groundwater, which is free from pathogenic microorganisms and available in adequate quantity in shallow aquifers. But, for a densely populated area like Satkhira district, where the population density and shrimp cultivation are increasing rapidly, it is not feasible to use the groundwater on a long term because the groundwater table continues to deplete and getting contaminated with salinity intrusion. This become a serious threat for public health in the region.

According to the ADB report 2011, salinity level has been increasing in the last several years in the Khulna, Bagerhat and Satkhira district. Factors like prolonged dry weather and rising sea levels, may cause for increase in salinity levels even further. Moreover, because of upstream water withdrawal by the neighboring country India at the Farakka barrage, which started its operation in 1975 , reduces the dry season flow of Gorai river severely, causing the tidal flow to encroach into the inland further. This river is one of the distributaries of Ganges river and a major source of freshwater in this division [1]. Apart this, a large area of Satkhira and Jessore districts currently suffer from recurring and worsening water logging that can be exacerbated by increased rainfall and rising sea levels caused by climate change. 
In the above context, search for a new potable water supply source is essential for Khulna division. Rainwater is the only source, which is easy to collect individually with a minimum cost. Rainwater harvesting system requires a collection basin or cathment, usually the roof of the house to harvest rainwater, a piping arrangement and a container to store it. The collected rainwater can be utilized to reduce the shortage of water for safe drinking, cooking and dishwashing purposes [5]. The main objective of the study is to develop a sustainable rainwater harvesting system along the coastal region of Bangladesh and to assess its feasibility and acceptability to the rural people, especially for the study areas of Satkhira district in Khulna division.

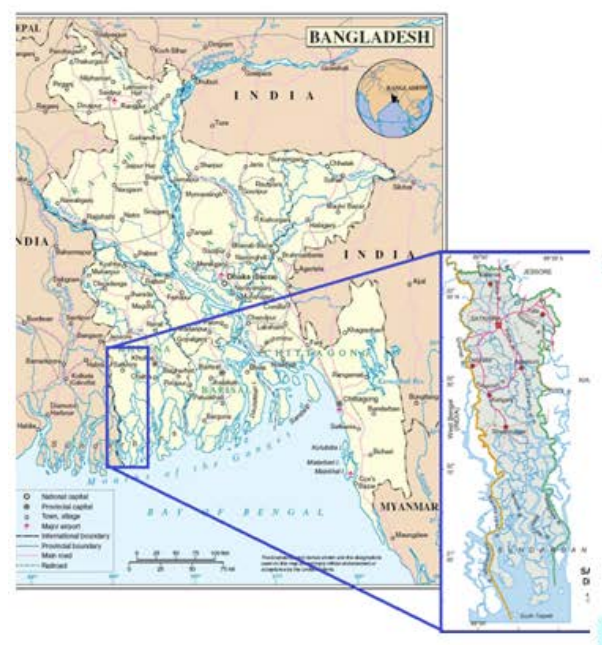

\section{Materials and Methods}

\subsection{Description of the Study Area}

The study area Patkelghata in Satkhira district was selected for its flat landscape marked by a little climatic fluctuation by the incidence of rain throughout the year. Comprised between 21'50 to 22'50 of latitude north and 89' to 89'20', of longitude east, Patkelghata is located in the Satkhira district on the southwest part of Bangladesh, at 6 meter (20 feet) above the sea level. The territory extends over an area of $344 \mathrm{~km}^{2}$, covered mainly by plains $[4,6,15]$. The location of the study area indicated in the following Figure 1.

Figure 1. Location of study site, Satkhira district, Bangladesh $[15,16]$

\subsection{Water Collection Options}

The water used by the local population is collected from surface water (river and pond), underground water and rainwater during monsoon. A small proportion of villagers are connected to municipal water supply. The Satkhira municipality has deep tube well and one overhead tank. The pipe network distribution system is situated around the town. A small proportion of people outside the town can get drinking water from Satkhira town directly. The distance of study area to Satkhira municipality is 14 kilometer. Recently, Dhara a nongovernment organization has installed a deep tube well in Patkelghata and made a local water supply network. This piped water supply system can supply only one kilometer radius from its pump house. So, the majority of people have to fetch water from district municipal water supply system. The water convenience cost is 80 cent per container (25 liters) per day. A five-member family size needs minimum a container water for only drinking purpose, i.e. monthly about \$24 expenses for drinking water purpose. It is very hard to afford monthly such utility bill for the poor people.

\subsection{Climatic and Meteorological Data Analysis}

\section{Rainfall analysis}

The climate of Bangladesh is characterized with high temperature, heavy rainfall, excessive humidity and seasonal variation. In rainy season, rainfall occurs due to north-easterly winds and annual rainfall varies from 1,250 $\mathrm{mm}$ to $3,500 \mathrm{~mm}$ [5]. Annual rainfall in Bangladesh is shown in the following figure. Annual rainfall below $1,500 \mathrm{~mm}$ found in the Middle West part and annual rainfall more than 3,000 $\mathrm{mm}$ found in the north east hilly area and south east forest areas in Bangladesh. According to the figure, the annual rainfall in the study area is between 1,800 to $2,100 \mathrm{~mm}$.

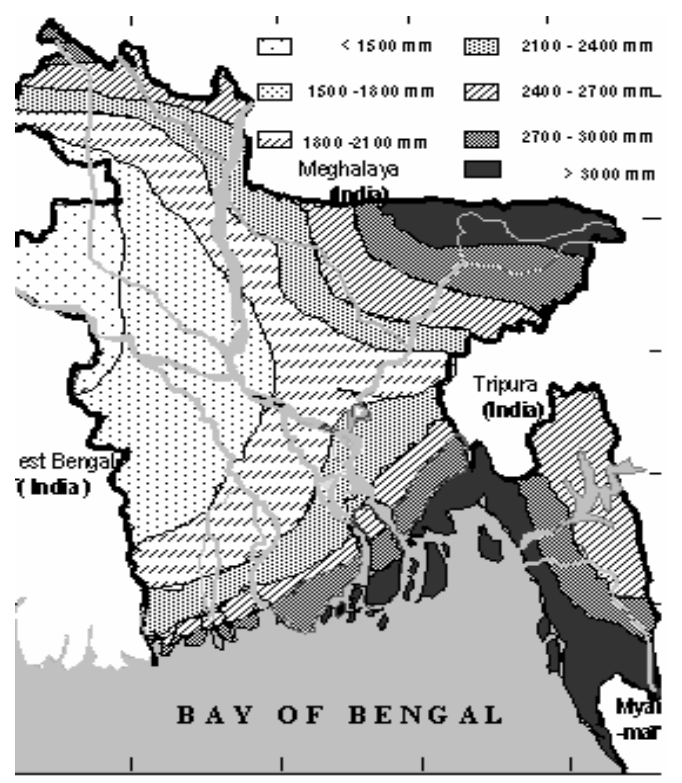

Figure 2. Annual Rainfall in Bangladesh [2] 
The rainfall pattern is based on the mean rainfall intensity. The average yearly rainfall in the country during 1958-2010 varied from 1,500 to $2,800 \mathrm{~mm}$ i.e. 1.5 to 2.8 $\mathrm{m}^{3}$ of rainwater was available per square meter of catchment area each year for development of rainwater based water supply system [5]. Monthly average precipitations in Satkhira shows distinct seasonal variations with maximum in July $375 \mathrm{~mm}$. This district experiences regular rainfall all the year round, and the locality of Patkelghata experience highly variable rainfall and a distinct short dry season from December to March.

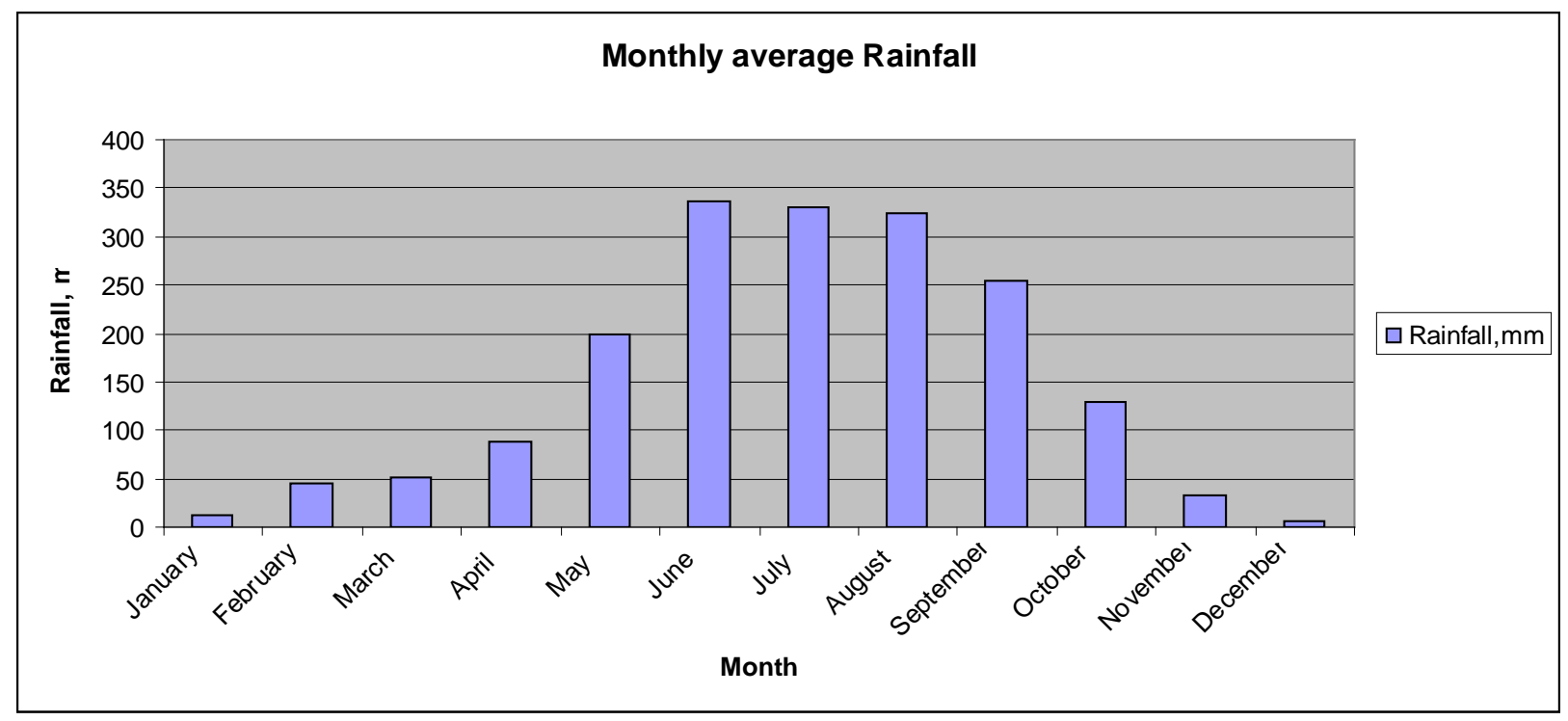

Figure 3. Monthly average rainfall in Satkhira district (BMD, 2013)

\subsection{Dimensioning of Rainwater Collection Systems}

The volume of rainwater was estimated by the system assessed through the Rational Equation and the dimensioning the required storage set in accordance to the method developed by Ahmed and Rahman [7].

\subsection{Potential Rainwater Harvesting Flow Rate}

The potential for rooftops (catchment) to collect rainwater is dependent on the area of the interception surface, the intensity of the rain and the nature of the catchment material.

For this study, a family consisting of five members having water demand of 5 l/capita/day for 3 months (for only drinking and cooking purpose) was considered. [7].

The available rainwater was estimated by the equation

$$
Y=(f \times A \times R) / 1,000 \mathrm{~m}^{3}
$$

Where $Y$ is the amount of water yielded per month,

$f$ is the catchment's efficiency or coefficient of available runoff,

$R$ is monthly rainfall ( $\mathrm{mm})$ and $A$ is the catchment area in square meters.

The minimum catchment area $A$ required for the collection of rainwater for $N$ number of people supplied with $q$ liters per capita per day (lpcd) for the intensity of rain fall I, it can be deduced from the equation [7].

$$
A=0.365(q N) /(f I)
$$

About $25 \%$ of the rainwater should be presumed to be lost by evaporation and for washing the catchment area using first rain that produces inferior quality rainwater [7].
The Eq. (2) can be written for an average annual rainfall of $2.46 \mathrm{~m} /$ year, and a coefficient of runoff of 0.70 in the following form [7]:

$$
A=0.212 q N
$$

\subsection{Catchment Area Calculation}

There are different types of roofs found in southwest coastal region in Bangladesh. The rural people are poor and unable to make extra catchment for rainwater harvesting. Therefore the traditional roof made by tiles, Corrugated Iron (CI) sheets or tin, concrete or straw have to be used as roof catchment. Different types of roof orientation in the rural area were considered for rainwater collection catchment area. Concrete roof is plain and parallel to ground surface. Tile, tin and straw made roofs look like triangles with slope.
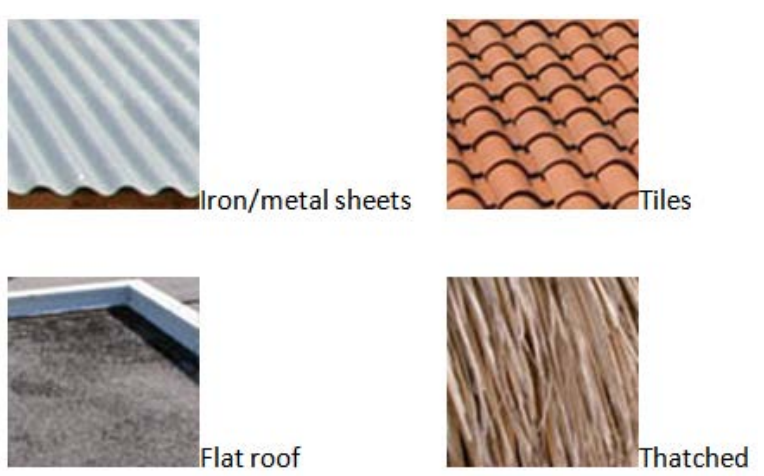

Figure 4. Rainwater harvesting roof top catchment - iron/metal sheets, tiles, flat roof, thatched

Concrete roof area is calculated by multiplying width and length. CI sheet or tin and tiles made roofs are different than concrete roof. This type of roof area is calculated in a different way. 
Catchment area, $\mathrm{A}=\mathrm{L} * \mathrm{~W}(\mathrm{~L}=$ length and $\mathrm{W}=$ width $)$

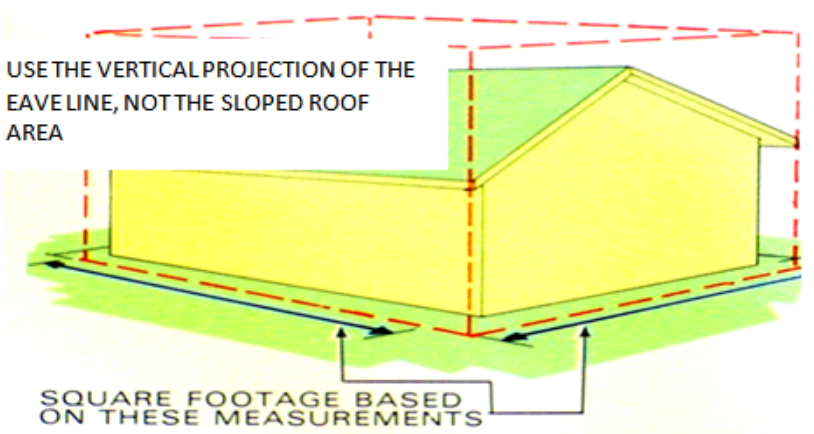

Figure 5. Roof Catchment Area

\subsection{Rainwater Collection Procedure}

There are four types of roof structures available in that area. Samples were collected from normally found rural household roof made of corrugated sheet (tin), roof tiles, flat roofs and thatched. Twelve samples were collected from the middle of June to the end of August, 2012.

Normally the samples were collected after 20 to 30 minutes of heavy rainfall. The physical and chemical tests were conducted for color, total dissolved solids, lead, turbidity, hardness, acidity, $\mathrm{p}^{\mathrm{H}}$, nitrate, fluoride. The chemical analysis was performed according to the standard methods for the examination of water and wastewater. On the other hand, microbiological tests were conducted for Total Coliform (TC) and Fecal Coliform (FC). Each rainwater sample was tested. The samples were tested at Bangladesh Agricultural Development Corporation (BADC) water testing laboratory, Irrigation wing, Jessore district.

\subsection{Questionnaire Survey}

A structured questionnaire was developed to understand the people's knowledge, views and opinion, a acceptability of using rainwater for domesic pruposes, problems and prospect related, prospective management options, etc. The questionnaire was developed through prior discussion with rural people. Then the questionnaire surveys were conducted with various groups of inhabitants of that area. The groups consisted of students, farmers, religious leaders (Imams), teachers and housewives. The survey was conducted among the students and teachers of Haruner Rashid College, Patkelghata, Tala upazilla, and religious leaders were from different parts of the district. Farmers and housewives were from Patkelghata area of Satkhira district. The results of the questionnaire survey has been presented at different sub-sections of the next section "Result".

\section{Results}

\subsection{Proposed Low Cost Rain Water Harvesting System}

Based on rural housing of the southwest region, a rain water harvesting system in the rural area consists of elements as roof catchment, gutters, down pipes, first flush devices, filter chamber and storage tank. Here a proposed design for typical rural rooftop rainwater harvesting system has been demonstrated.

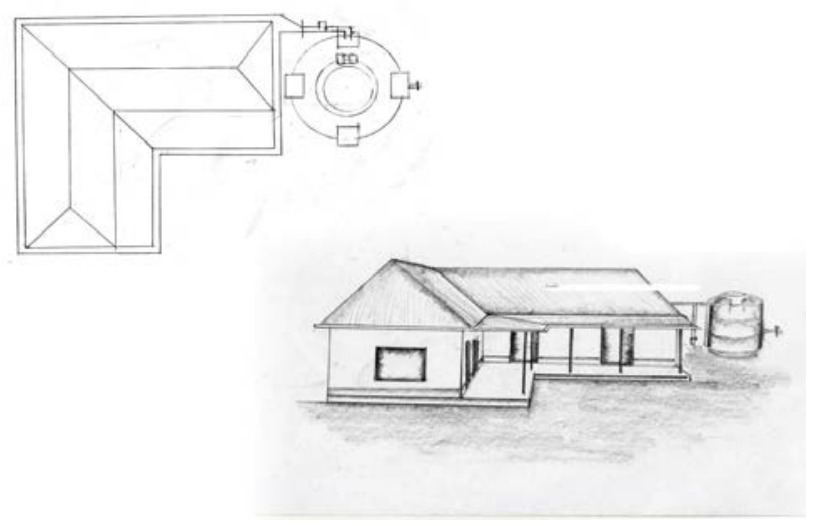

Figure 6. Proposed design and typical rural rooftop rainwater harvesting diagram

Table 1. Cost estimation of rainwater collection system

\begin{tabular}{|c|c|c|c|c|}
\hline & & & Unit price(\$) & Total price(\$) \\
\hline \multirow{11}{*}{ Structural material } & Gutters & $10 \mathrm{~m}$ & 0.31 & 3.1 \\
\hline & Pipe $(2$ inch $\varphi)$ & 16 feet & 0.5 & 8 \\
\hline & Pipe $(3 / 4$ inch $\varphi)$ & 1 feet & 0.25 & 0.25 \\
\hline & Cup (Holler type) & 1 piece & 2.5 & 2.5 \\
\hline & T socket & 1 & 0.63 & 0.63 \\
\hline & Tар & 1 & 0.82 & 0.82 \\
\hline & Lock & 1 & 0.19 & 0.19 \\
\hline & Great ball (2 inch ) & 2 & 5.63 & 11.25 \\
\hline & L lbo & 2 & 0.5 & 1 \\
\hline & Brick $(9.5 ” \times 4.5 ” \times 2.5 ”)$ & 50 & 0.06 & 3.13 \\
\hline & Tank (1000 liter) & 2 & 60 & 120 \\
\hline & Labor & & 15 & 15 \\
\hline & \multicolumn{2}{|c|}{ Annual maintenance } & 5 & 5 \\
\hline & \multicolumn{3}{|c|}{ Total } & 170.87 \\
\hline
\end{tabular}

By keeping in mind that this research aims to promote an inexpensive and easy way to get fresh water to meet the needs of rural population, the entire system has to deal with the financial aspect of each household at the first place and secondly to promote the use of local materials in the construction phase. After all the calculations, a total amount of $\$ 171$ would be necessary for building and operating whole system. The table presents the list, unit price and total price of all materials that would be required. Unit price is only applicable in Bangladesh. Unit price for 
this proposed system may vary in other countries all over the world.

\subsection{Storage Tank Capacity}

According to equation-(iii) the minimum catchment's area, A required for collection rainwater for a rural household is $6 \mathrm{~m}^{2}$.. The annual water requirement of a rural family (six members) in the south west region of Bangladesh is $11 \mathrm{~m}^{3}$. The annual yield of rainfall is calculated $8.26 \mathrm{~m}^{3}$ by the minimum catchment area 6.09 $\mathrm{m}^{2}$ and estimated to be enough to fulfill the required demand of water. Usually the average maximum dry spell period in the region is around 45 days, i.e. gap in two rainfall occurrences is maximum around 45 days on an average for different years in dry season. For storage calculation the dry spell duration between two rainfalls is taken 60 days. So, sixty days demand is 2000 liter and it is suggested to build storage tank equal to 2000 liter capacity.

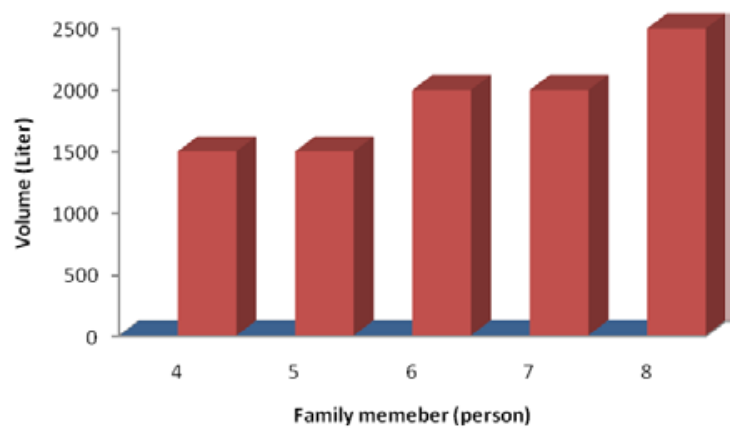

Figure 7. Storage tank required for various rural family sizes.

The bar chart shows the water demand in liter for various rural families. A rural family consists of four to five members, needs fifteen hundred liter water and a family size six to seven members needs two thousand liter per sixty days. The bar chart can also be used to determine storage container size according to family members. Here demand is calculated for sixty days period.

\subsection{Roof Materials}

Different types of roofing materials are used in rural areas in Bangladesh. These include cement concrete, tiles, CI (Corrugated Iron)/ metal sheet, straw with or without polythene covering. About 47 percent households in rural areas have Tin (Corrugated iron or metal sheet). Other materials include concrete and tiles with around 24 percentage each type. These roofing materials are suitable for using as rainwater catchments. Few people use straw as the roofing materials. However, this cannot be used directly as catchment, but after some modification such as polythene covering for straw.

\subsection{Roof Area $\left(\mathrm{m}^{2}\right)$}

There is no data available on the average roof size in rural areas in Bangladesh. In the field survey, it was found that about 58 percent of household's roof are within 25 to 50 square meters. About 22 percent of roofs are within 9.5 to 25 square meters. On the other hand, about 11 percent roof size is within 50 to 100 square meters and 9 percent above 100 square meters size. The minimum catchment area was estimated $6.09 \mathrm{~m}^{2}$ to be enough to fulfill the required demand of water.

\subsection{Household Size in Rural Area of Bangladesh}

Household size is one of the important parameters in designing a rainwater harvesting system. It is required to determine the total water demand, catchment area and storage volume. About 64 percent families have 4 to 5 persons and 89 percent families have 3 to 7 persons. The average household size is taken as 6 for the calculation of design storage capacity.

\subsection{Drinking Water Sources}

Tube well is very popular drinking water source all over in Bangladesh. In the survey, on an average twenty one households were collecting water from a tube well. Similarly twenty four households collect water from a municipal water supply. Deep tube well is used to collect water for municipal water supply. Open well and pond water is not popular for drinking purpose due to contamination.

A question was used to investigate the distance from home to water sources. According to the survey, about 18 percent people collect pure drinking water from 10-15 km and same percentage from $500 \mathrm{~m}, 16$ percent people collect pure water from $1-5 \mathrm{~km}$. Similarly only 17 percent people collect water from their own shallow tube-well.

A question was set to know the reason for collecting water from long distances. They have water around them but the water is polluted by arsenic, high salinity level and high iron and hardness level. The smell of tube-well water is not good in some cases. Out of 45 people's opinion, 19 persons indicated arsenic and 22 persons find water contain high levels of salt. Many people have stomach pains and are aware about arsenic contamination and water hardness. For that reason, they collect water from long distances.

In this survey, about 85 percent of people were harvesting rainwater at the time of monsoon. Similarly, approximately 82 percent of people drink rainwater and about 96 percent use rainwater for cooking. All people in this survey agreed that rainwater is safe for drinking.

Almost all students and teachers agreed to the question that quality and supply can be improved by harvesting rainwater after 15 minutes. On the other hand 9 farmers have no proper idea about rainwater quality and one farmer want to boil for quality improvement.

Nearly all people in this region use rainwater for cooking purpose in the rainy season. Rural people know that rainwater is safe for drinking and cooking. However, they cannot use rainwater properly due to lack of rainwater harvesting technology and setup. Local government such as Union Parishad and Upazilla Parishad and local NGOs can implement rainwater harvesting system at household level. Many government departments such as Department of Agriculture Extension, Public Health Engineering Department and Local Government Engineering Department could be engaged for RWH system implementation and technical support. Moreover, all attendants have same opinion about raising awareness to implement rainwater harvesting system. Political and religious leader can take part to increase awareness. Similarly, mass media should be most effective way to increase awareness. 


\subsection{Rain Water Quality}

To obtain accurate, reliable and representative data, the water samples were collected after 15 minutes of rainfall.
The tests were conducted for two times and the values of different parameters were compared with those of standards for drinking water in Bangladesh.

Table 2. Rain water quality

\begin{tabular}{|c|c|c|c|c|c|c|c|}
\hline Name of Parameter & Unit & Bangladesh Standard limit & Open air & Tin & Tiles & Concrete & Straw \\
\hline $\mathrm{pH}$ & & $6.5-8.5$ & 6.2 & 6.3 & 6.25 & 6.35 & 6.45 \\
\hline EC & $\mu \mathrm{S} / \mathrm{cm}$ & $600-1000$ & 101.7 & 105 & 107 & 115 & 290 \\
\hline TDS & $\mathrm{mg} / \mathrm{L}$ & 1000 & 71.19 & 80 & 75 & 80 & 203 \\
\hline Iron & $\mathrm{mg} / \mathrm{L}$ & $0.6-1.0$ & 0.2 & 0.5 & 0.2 & 0.25 & 2 \\
\hline Arsenic & Ppb & 50 & $>10$ & $>10$ & $>10$ & $>10$ & $>10$ \\
\hline Lead & $\mathrm{mg} / \mathrm{L}$ & 0.05 & 0.032 & 0.029 & 0.028 & 0.029 & 0.029 \\
\hline Color & TCU & 15 & 10 & 12 & 12 & 15 & 30 \\
\hline Turbidity & NTU & 10 & 0.80 & 0.82 & 0.80 & 0.82 & 0.83 \\
\hline Fecal Coliform & $\mathrm{N} / 100 \mathrm{ml}$ & 0 & 0 & 0 & 0 & 0 & 0 \\
\hline
\end{tabular}

\section{Discussions}

Rainwater harvesting is a potential alternative water source at present all over the world. Some references opined that rainwater harvesting has vast socio-economic importance in areas where all water sources are scares or polluted [8]. Another reference expressed that rainwater harvesting is ideal for Bangladesh due to plenty of rainfall during monsoon [5]. Traditional collection system renders rainwater harvesting quite feasible at the household level. Disadvantages of rainwater harvesting include a significant space requirement for the storage tank and low mineral salt in rainwater. Mineral salt may be added to harvested rainwater to counter the problem of low mineral salt.

Satkhira is one of the densely populated districts of south west coastal region of Bangladesh. So, the space requirement for storing harvested rainwater constitutes a significant obstacle to implement the system. Rainwater harvesting is performed in several countries, but the quality indicators of rainwater vary from place to place due to environmental conditions (including potential pollution sources) and level of cleaning and maintenance during the collection and storage period. Of late, Government of Bangladesh has taken a decision in principle recently to furnish a new rule that each and every new building must have the rainwater storage system [9] and this is a good indication to implement this alternative water source system effectively.

Different materials can be used as gutters and down pipes. The cost of galvanized iron (G.I.) pipes is very high compared to other materials. Polyvinyl chloride (PVC) pipes are cheap and available in coastal region of Bangladesh. The PVC pipes are suitable for gutters and down pipes. A storage tank is the most expensive component of rainwater harvesting system. Storage tanks are constructed from different materials. Now plastic tanks are cheap and available all over Bangladesh. The costs include gutters, down pipes, tap, storage tanks and labor cost. By keeping in mind that this research aims to promote an inexpensive and easy way to get fresh water to meet the needs of rural population, the entire system has to deal with financial aspect of each household at the first place and secondly to promote the use of local material in the concept. After all the calculations, a total amount of $\$ 171$ for 2000 liter capacity would be necessary for building and operating whole system. However, the amount seems to be still low, as some references mentioned that that a rainwater harvesting system with
15000 liter capacity may cost up to $\$ 1620$ [10]. So, the low cost rainwater harvesting system proposed in this study will be more attractive and sustained in the coastal areas of Bangladesh.

The first test result for color of rainwater collected from straw made roof, 30 NTU, exceeded the acceptable limit. The color content level of rainwater in other roofs was found within the standard limit. Most people can detect colors above 15 true color units (TCU) in a glass of water. Levels of color below 15 TCU are usually acceptable to consumers, but acceptability may vary [11]. High color could also indicate a high propensity to produce byproducts from disinfection processes. No health-based guideline value is proposed for color in drinking-water.

The $\mathrm{pH}$ value is an important parameter of safe drinking water quality. The standard $\mathrm{pH}$ values of rainwater vary approximately from 6.5 to 8.5 . The values may differ due to the mixing of other chemical components from the air or roof catchment or from storage tank. Khemani et al. expressed that the $\mathrm{pH}$ values in Indian cities Agra and Delhi have been found to have decreased by 2.8 (9.1 to 6.3) and 0.9 (7.0 to 6.1) units, respectively after the period of two decades during which the old cities developed industrially to a great extent[12]. The main cause for the decrease in the $\mathrm{pH}$ values was a significant increase of acidic components and decrease of soil-oriented components in the rainwater. Ariyananda stated that the $\mathrm{pH}$ values in the cement tanks decrease during the wet season and increase during the dry season[13]. She investigated the $\mathrm{pH}$ values of rainwater in different countries. She also recorded the mean $\mathrm{pH}$ value in urban area of Ethiopia was 8.2, 8.8 in Uganda and 9 in rural areas of Sri Lanka. In another study, the $\mathrm{pH}$ values of collected rainwater were found 7.63 to 8.8 with a mean value of 8.35 [13]. They had collected the rainwater into ferro-cement storage tanks. The rainwater was collected from the cement-paved hill slopes and it served as catchment areas. But some of the other studies reported that the $\mathrm{pH}$ values for rainwater varied from 4.17 to 6 , which means the rainwater of those places is acidic [14]. The $\mathrm{pH}$ values of the rainwater of this study were within the Bangladeshi standard and the values were from 6.2 to 6.45 , which indicated that the collected rainwater was a bit acidic. But the test results of this research were still within the acceptable range of Bangladeshi drinking water standard.

Iron is an essential nutrition element for human health. Minimum daily requirement of iron for human body depends on age, sex, physiological status and range from about 10 to $50 \mathrm{mg}$ per day. According to WHO, 
groundwater may contain iron (II) at concentrations up to several milligrams per liter in the water when directly pumped from a well [11]. Usually taste is not noticeable at iron concentrations below $0.3 \mathrm{mg} / \mathrm{liter}$. The test results of all samples are within acceptable limit except straw sample that exceed the permissible limit.

In a number of countries, the World Health Organization interim arsenic guidelines of $0.01 \mathrm{mg} / \mathrm{L}$ have been adopted as the standard. However, many countries have retained the previous WHO guideline of $0.05 \mathrm{mg} / \mathrm{L}$ as the national standard. Many European countries have adopted the WHO provisional guideline of $0.01 \mathrm{mg} / \mathrm{L}$ as their national standard. A number of Countries where the national standard for arsenic in drinking water remains at 0.05 mg/L include Bangladesh, China and India [11]. The collected samples are below the Bangladesh national arsenic standard.

When the storage period elapsed three months then some total coliforms bacteria were found in the stored rainwater (8, 9 and $11 / 100 \mathrm{ml}$ respectively). This total coliform might enter into the tank mixing with air through the inlet of the storage tank. To avoid such kind of contamination, the storage tank should be well monitored and maintained during the stored period. To reduce total coliform from the stored rainwater, locally made sand filter can be used. Public acceptability of the degree of hardness of water may vary considerably from one community to another, depending on local conditions. The taste threshold for the calcium ion is in the range of 100$300 \mathrm{mg} / \mathrm{l}$, depending on the associated anion, and the taste threshold for magnesium is probably lower than that for calcium. It is not a pollution parameter but is a quality indicator. In some instances, consumers tolerate water hardness in excess of $500 \mathrm{mg} / \mathrm{l}$ [11]. Depending on the interaction of other factors, such as $\mathrm{pH}$ and alkalinity, water with hardness above approximately 200 mg/l may cause scale deposition in the treatment works, distribution system and pipe work and tanks within buildings. Soft water, with a hardness of less than $100 \mathrm{mg} / \mathrm{l}$, may, on the other hand, have a low buffering capacity and so be more corrosive for water pipes. No health-based guideline value is proposed for hardness in drinking-water [11].

\section{Conclusion and Recommendation}

The study concentrated on finding a solution of potable water supply for a large mass of population living along the south-western coastal region of Bangladesh, who are suffering from acute shortage of freshwater for domestic purposes due to salinity intrusion, arsenic contamination of groundwater, etc mainly caused by excessive use of groundwater, upstream withdrawal of freshwater, development activities like shrimp cultivation, etc. Being located in the Asian monsoon belt, Bangladesh got a large amount of rainfall during monsoon so that rainwater harvesting has been considered as a prospective option. However, because of seasonal variability of rainfall, with quite a long dry spell of up to 45 days period during winter, it may need a large storage reservoir to be built. Quality of rainwater and economic viability of the structure were few other factors to be considered. After all these consideration, a sustainable design of rainwater harvesting system was proposed, which is economically viable and structurally stable. The minimum catchment's area required for collection of rainwater for a rural household was found to be $6 \mathrm{~m}^{2}$. In addition, the annual water requirement of a rural family based on six members was calculated as $11 \mathrm{~m}^{3}$. Moreover, water demand has been calculated as two thousand liters for a six to seven members family. Finally, it can be suggested that average rural houses based on six members can build a storage tanks with a capacity of 2000 liter. Moreover, a low cost rain water harvesting system is proposed. The cost of the system is $\$ 171$ and it is assumed to be affordable in the region.

The questionnaire survey revealed the roof orientation and structures of rural house roof which could be used as catchment (to collect the rainwater) and available size of rural house roof areas. The survey result also revealed that the roof condition of the selected area is suitable to use as catchment for rainwater. Moreover, the available average sizes of the roofs are suitable for an adequate size of rainwater harvesting system. The test results showed that the quality of rainwater was acceptable as safe drinking water without any treatment in southern part of Bangladesh. Rural people know that rainwater is safe for drinking and cooking. However, they cannot use rainwater properly due to lack of rainwater harvesting technology and implementation procedure. A further detailed survey on the rainwater acceptability in water scarce area like entire Khulna division can be conducted to get the more clear picture of the water requirements. Social campaign is also needed to create awareness about the rainwater as good alternative option.

Moreover, this test result was applicable only for this area, because there would be spatial variation of quality of rainwater due to variation of air quality or the environment. Further study should emphasize on careful handling of the storage tank and closing of the inlet. Further detail research on the rainwater storage tank may be conducted in future. Care should be taken during storage period to ensure that coliform cannot enter into the tank. So, the water can be used for the whole storage period as safe drinking water. In case of necessity, the water tank can be chlorinated as per standard guidelines. Finally, one could also recommend that once such systems are in operation, an investigation of the microbiology and the chemistry of the collected stored water in different areas should be initiated to monitor the proper operation and management of the systems.

\section{References}

[1] Banglapedia, 2014. National Encyclopedia of Bangladesh. Available through: http://bpedia.org/S_0134.php [Accessed 24 December 2013].

[2] Sumon F. R., Abul Kalam A K M, 2014. Rainwater Harvesting and the Scope of Enhancing Ground Water Table in Dhaka City. Dhaka Metropolitan Development Area and Its Planning Problems, Issues and Policies. Bangladesh Institute of Planners (BIP) Available through: <http://www.bip.org.bd/journalBook/44>. [Accessed 29 April 2014]

[3] Bangladesh Bureau of Statistics, 2012. Statistical year book of Bangladesh. Ministry of Planning, Govt. of People’s Republic of Bangladesh, Dhaka, Bangladesh. http://www.bbs.gov.bd/PageWebMenuContent.aspx?MenuKey=4 4

[4] Asian Development Bank, 2011. Adapting to Climate Change Strengthening the Climate Resilience of The Water Sector 
Infrastructure In Khulna, Bangladesh. Asian Development Bank, 6 ADB Avenue, Mandaluyong City, 1550 Metro Manila, Philippinnes, Available through: <www.adb.org> [Accessed 4 April 2013].

[5] Islam M M., 2010. Feasibility and acceptability study of rainwater use to the acute water shortage areas in Dhaka City, Bangladesh, Nat Hazards (2011) 56: 93-111.

[6] Worldatlas.com, Available through: <http://www.un.org/depts/Cartographic/map/profile/banglade.pdf, http://maps-of-bangladesh.blogspot.com/2010/10/political-mapof-satkhira-district.html>, [Accessed 12 March 2014]

[7] Ahmed, M. F., \& Rahman, M. M., 2000. Water supply \& sanitation: Rural and low income urban communities. ITNBangladesh, Centre for Water Supply and Waste Management, BUET.

[8] Zhu K, Zhang L, Hart W, Liu M, Chen H (2004) Quality issues in harvested rainwater in arid and semi-arid Loess Plateau of Northern China. J Arid Environ 57: 487-505.

[9] The New Nation, 2009 solar energy to be used in public buildings. Available through: <http://nation.ittefaq.com/issues/2009/10/23/news0487.htm,> [Accessed 10 July 2012]
[10] Dakua, M., 2012. Discussion on costing of a rainwater harvesting. [Letter] (Personal communication, 10 September 2013).

[11] World Health Organization, 2008. Guidelines for drinking-water quality, 3nd ed. World Health Organization, 20 Avenue Appia, 1211 Geneva 27, Switzerland (incorporating 1st and 2nd agenda)

[12] Khemani LT, Momin GA, Rao PSP, Safai PD, Singh G, Chatterjee RN, Prakash P., 1989 Long-term effects of pollutants on $\mathrm{pH}$ of rain water in North India. Atmos Environ (1967) 23 (4): 753-756.

[13] Ariyabandu, R. De S., 2003. Very-low-cost domestic roof water harvesting in the humid tropics: its role in water policy. DFIDKar Contract R783, Report R4, Prepared By, Lanka Rainwater Harvesting Forum.

[14] Mantovan P, Pastore A, Szpyrkowicz L, Zilio-Grandi F (1995) Characterization of rainwater quality from the Venice region network using multiway data analysis. Sci Total Environ 164: 2743

[15] Bangladesh Meteorological Department, 2013. Available through :<http://www.bmd.gov.bd/> [Accessed 24 December 2013].

[16] Institute of Water Modeling (IWM), 2013, Available through http://www.iwmbd.org/ 